\title{
PEMAHAMAN MAKNA HADITS TINJAUAN TEKSTUAL DAN KONTEKSTUAL
}

\section{Iklil Hasbiyalla}

Ekolah Tinggi Ilmu Syariah Darul Falah Bondowoso

Email : iiklilhasbiyalladafa@gmail.com

\begin{abstract}
Abstrak
Pemahaman terhadap teks hadits itu selalu mengalami dinamika, tidak ubahnya dalam paradigma penafsiran al-qur'an. Istilah pemahaman tekstual dan kontekstual yang selama ini didengungkan oleh para cendekiawan muslim kontemporer, merupajan suatu pemetaan saja, bukan suatu model suatu pemecahan saja, masalah ini tetap merupakan suatu yang masih problematik, perlu dikaji ulang dan dikembangkan lagi. Kajian ini membuka cakrawala tentang pemaknaan hadits baik secara tekstual dan kontekstual.
\end{abstract}

Kata Kunci : Teks Hadits, Tekstual, Kontekstual

\section{Pendahuluan}

Permasalahnan di sekitar bagaimana memahami makna hadits bisa dikatakan lebih "menantang" jika dibandingkan dengan penafsiran ayat-ayat al-qur'an. Dalam memahami al-qur'an, hadits bisa dijadikan sumber dan alat untuk menjelaskan makna ayat, ${ }^{1}$ selain juga bisa dengan pendekatan lain seperti rasio, sejarah, bahasa, dan sebagainya. ${ }^{2}$ Namun tidak sedemikian halnya dalam memahami makna hadits. Untuk memahami suatu hadits tidak ada teks lain di bawah tingkatan hadits itu sendiri yang secara secara formal mendapat legitimasi dari al-qur'an kecuali berupa syarh dan hasyiyah yang semakna denga tafsir dalam menjelaskan makna ayat al-qur'an. Dengan demikian, pemahaman suatu hadits belum mendapat justifikasi yang kuat kecuali dari hadits itu sendiri, atau merujuk kembali pada teks al-qur'an.

\footnotetext{
${ }^{1}$ Salah satu fungsi hadits memang untuk menjelaskan arti dan makna ayat-ayat al-Qur'an sebagaimana telah ditunjukkan sendiri dalam al-Qur'an, misalnya surat an-Nahl ayat 44. "Dan kami turunkan kepadamu al-Qur'an agar kamu menerangkan kepada umat manusia apa yang telah diturnkan kepada mereka. ” Dan juga ayat 68 dan 89. Juga dalam surat al-Maidah ayat 67.

${ }^{2}$ Sebagaimana al-Qur'an, hadits juga dipahami dengan makna dan corak yang berbeda-beda oleh ulama yang mempunyai diplin ilmu yang berbeda pula, seperti muhaditsin, usuliyin, fuqaha', lughawiyin, rasionalis, sosiolog, dan politikus.
} 
Permasalahan selanjutnya adalah adanya kecenderungan pemahaman terhadap hadits yang bermuara pada dua tipologi, tekstual yang cenderung mempertahankan arti dan makna hadits itu sebagaimana tertulis, dan kontekstual yang mengarah kepada pemekaran dan pengayaan makna hadits yang disesuaikan dengan konteksnya yang diusahakan bisa berdialog langsung dengan perkembangan sosial budaya sekarang.

Pemekaran makna hadits dengan model kontekstualisasi ini, selain dipengaruhi oleh hal diatas, juga bisa disebabkan oleh kapasitas diri Nabi Muhammad Saw. yang bermacammacam, seperti sebagai Rasulullah, mufti, qadhi, pemimpin masyarakat, dan sebagainya.

Dalam kapasitasnya sebagai Rasulullah, maka hadits nabi itu pasti benar, sebab bersumber dari Allah. Demikian juga kepastian kebenarannya dalam kapasitasnya sebagai mufti, yang memberi fatwa berdasarkan pemahaman dan wewenang yang diberikan Allah. Dalam posisinya sebagai hakim, walaupun secara formal hadits itu benar, namun secara material adakalanya keliru. Sebagai pemimpin masyarakat, hadits nabi pasti benar dan sesuai dengan masyarakanya, namun bagi masyarakat yang lain, mereka dapat mempelajari nilai-nilai yang terkandung dalam petunjuk hadits itu untuk diterapkan sesuai dengan kondisi masing-masing masyarkat, atau hadits, dalam hal ini, dapat dikontekstualisasikan. Sedang sebagai pribadi, hadits nabi bisa dipilah, pribadi manusia biasa, yang terakhir ini akan merelatifkan makna hadits. ${ }^{3}$

Berkaitan dengan persoalan di atas, antara pemahaman hadits secara tekstual dan kontekstual, sangat menarik untuk diteliti kembali beberapa hadits nabi yang bisa dikatakan mempunyai dua dimensi makna tersebut, bahkan bisa dimekarkan lagi makna yang tersurat dan yang tersirat di dalamnya.

Pertama, hadits yang berkaitan dengan wanita yang bepergian sendiri. Hadits ini telah diinterpretasikan secara berbeda oleh beberapa pakar seperti Yusuf Qardhawi, Majdi Sayyid Ibrahim, Al-Zurqani dan Al-Nawawi dengan pendekatan yang berbeda, dan ini cukup menarik untuk diteliti dan dianalisis kembali.

Kedua, hadits yang berkenaan dengan keberadaan dunia sebagai penjara orang mukmin dan surganya orang kafir. Hadits ini juga perlu dikaji ulang makna tekstual atau

\footnotetext{
${ }^{3}$ Pemilahan hadits yang dikaitkan dengan kapasitas Nabi ini untuk kali pertaa dikemukakan oleh Imam alQarafi, demikian menurut M.Quraish Shihab dalam, Kata Pengantar Studi Kritis atas Hadits nabi SAW, karya Syaikh Muahammad al-Ghazali, Bandung, Mizan, 1996, hal. 9-10. Lihat juga, M. Quraish Shihab, Hubungan Hadits dan al-Qur'an: Tinjauan Segi Fungsi dan Makna, dalam Yunahar Ilyas dan M. as'udi, ed., Pengembanagn Pemikiran Terhadap hadits, Yogyakarta, LPPI UMY, 1996, hal. 56-60.
} 
kontekstualnya mengingat para ulama yang pernah membahasnya melihat dari kaca mata fiqih dan tasawuf, dan ini perlu dimekarkan kembali.

Ketiga, hadits yang terkait dengan masalah kepemimpinan dan politik, yaitu bahwa pemimpin itu dari suku Quraisy. Telaah atas hadits ini telah banyak dilakukan orang, namun demikian makna hadits ini perlu dikontekstualisasikan kembali dengan melihat pada permkembangan budaya dan politik dewasa ini.

\section{Pemahaman Makna Hadits Tentang Wanita Tidak Boleh Bepergian Sendiri}

Ada beberapa redaksi hadits yang berkaitan dengan hal ini. Dalam kitab Lu'lu' wa alMarjan, bab safar al-mar'ah ma'a mahramin ila hajjin wa gahirihi disebutkan beberapa hadits: ${ }^{4}$

Dari redaksi hadits-hadits tersebut, ada beberapa sifat atau ikatan yang menyertai diri wanita yang mengadakan perjalanan jauh. Ada batasan hari atau lama perjalanan dan sifat wanita yang mukmin dan percaya dengan hari akhir. Dari redaksi yang berbedabeda ini sudah bisa diduga ada indikasi perbedaan makna tekstualnya. Atau bisa juga hadits-hadits ini diriwayatkan secara maknawi, sehingga menimbulkan perbedaan lafadh.

\section{Tinjauan Tekstual}

Memahami hadits secara tekstual bukan berarti permasalahannya hanya berhenti pada mengikuti teks yang ada, tetapi lebih dari itu ada problem yang selalu mengitarinya, terutama yang berkenaan dengan maksud dari lafadh-lafadh tertentu.

Berkaitan dengan hadits di atas, al-Zurqani dalam kitabnya Syarh al-Zurqani ala Muwatta' Imam Malik menjelaskan bahwa adanya sifat mukmin yaang melekat pada wanita menunjukkan adanya ta'kid larangan, yaitu pengharaman bagi wanita yang bepergian sendirian. Karena jika pergi tanpa disertai muhrimnya maka ia telah melanggar syarat iman Allah dan yaum al-akhir. ${ }^{5}$

Al-Zurqani dalam hal ini, secara tegas mengharamkan wanita bepergian tanpa muhrimnya. Selanjutnya ia juga menandaskan bahwa lafadh mar'ah bersifat umum

\footnotetext{
${ }^{4}$ Muhammad Fuad Abdul Baqi, Lu'lu' wa al-marjan fi ma Ittafaqa 'Alaihi al-Syaikhuna, Jilid 2, Beirut, Dar al-Fikr, hal. 73-74, Hadits Nomor 874, 848, 849, dan 850

${ }^{5}$ Muhammad bin Abd al-Baqi bin Yusuf al-Zurqani, Syarh al-Zurqani 'ala muwatta' Imam Malik, Juz 4, Beirut: Dar al-Kutub al-Ilmiah, 1990, hal. 502.
} 
berlaku untuk semua wanita, baik tua, dewasa, ataupun gadis. Pendapat ini juga dikemukakan oleh Qadhi Iyadh dan Imam Nawawi. Bagi Nawawi wanita itu mengundang syahwat baik gadis maupun wanita dewasa atau tua. Oleh karenanya larangan dalam hadits ini untuk semua wanita secara umum. Namun di sisi lain, al-Baji justru menegaskan bahwa semua ini hanya berlaku bagi wanita yang masih muda (gadis). Sedang wanita yang sudah tua dan tidak membangkitkan birahi maka ia bisa bepergian sekehendak hatinya dalam setiap bepergian tanpa harus disertai suami atau muhrimnya.

Sementara itu, majdi Sayyid Ibrahim menganggap hadits ini sebagai wasiat Rasulullah bagi wanita yang keluar dari rumahnya untuk bepergian. Sebagai wanita mukminah harus selalu mengikuti langkah-langkah Rasulullah, berusaha semampunya melaksanakan perintahnya dan menjauhi larangannya. Dilatarbelakangi dengan hal di atas, dalam kesimpulan uraiannya, ia mengharamkan wanita untuk bepergian sendirian tanpa disertai suami atau meuhrimnya, kecuali dalam hal perjalanan haji dan umrah. ${ }^{6}$ Kesimpulan ini ia perkuat dengan makna tekstual dari lafadh "la dan la yahillu" yang menurutnya berarti “la yajuzu” yang mengandung maksud pengharaman.

\section{Tinjauan Kontekstual}

Pemahaman terhadap hadits di atas secara kontekstual bisa kita masukkan di sini, pendapat Yusuf al-Qaradhawi. Dari sekian hadits yang berkaitan dengan larangan wanita bepergian sendirian ini, Qaradhawi hanya memaparkan hadits yang redaksinya

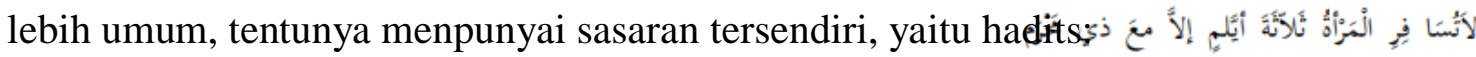

Menurutnya, secara historis sosiologis, aanya larangan di balik hadits ini muncul karena nabi khawatir bila wanita bepergian sendirian tanpa disertai suami atau muhrimnya dengan kondisi aman dan tempat yang sedemikian rupa, masih menggunakan unta atu keledai, di tempat yang sepi dan membahayakan, melintasi padang pasir yang jauh dari kampung dan perkotaan, maka itu semua akan membahayakan dienya. Oleh karenanya,

\footnotetext{
${ }^{6}$ Majdi Sayyid Ibrahim, 50 Wasiat Rasulullah Bagi Wanita, Terj. Kathur Suhardi, Jakarta, Pustaka alKautsar, 1995, hal. 218 dan 232.
} 
adalah wajar jika Nabi melarang hal ini bagi wanita, mengingat juga faktor keselamatan dan menjaga nama baiknya. ${ }^{7}$

Walaupun demikian, bagi Qaradhawi, alasan di atas sudah tidak relevan lagi bagi zaman sekarang. Dunia modern seperti sekrang ini situasi dan kondisi sudah tidak sama lagi dengan masa Rasulullah hidup. Untuk bepergian jauh pada masa sekarang tidak terkecuali bagi perempuan dapat dilakukan dengan cepat dan nyaman dan faktor keselamatannya lebih terjamin. Sekarang sudah ada pesawat, kapal, kereta, dan alat transportasi lainnya yang nyaman. Jadi, intinya hadits di atas sudah tidak relevan lagi untuk dipahami secara tekstual untuk masa sekarang, dan harus dikontekstualisasikan dengan pendekatab sosial budaya.

\section{Analisis Teks dan Konteks}

Dari kajian tekstual dan kontekstual di atas, dapat kita lihat bahwa pendekatan tekstual terhadap hadits tentang sendirian itu masih dalam diskusi yang belum terselesaikan. Makna teks yang mana yang ideal, apakah wanita itu mencakup semua umur, berlaku secara umum atau yang dimaksud wanita itu hanya para gadis saja, dan wanita mana yang sebenarnya yang menimbulkan syahwat bagi laki-laki, ini belum jelas dan masih dalam perdebatan. Belum lagi kalau masalah ini dikaitkan dengan jilbab yang dalam pandangan umum wanita yang berjilbab itu tidak merangsang syahwat, dan yang tidak berjilbab akan menggairahkan nafsu laki-laki yang memandangnya. Kalau memahami hadits ini dengan kriteria yang sedemikian rupa hasilnya relativitas, sangat subjektif.

Di sisi lain, apakah larangan yang disimbolkan dengan lafadh "la atau la yahillu" itu menunjukkan pada pengharaman, yang konsekuensinya, tentunya hadits tersebut akan mempunyai nilai hukum yang ketat, harus ditaati atau dihindari, dan tidak ada tawar menawar. Kalau kita lihat dari apa yang kemukakan oleh al-Zulqarni, Qadhi 'Iyadh, Imam Nawawi, dan Majdi Sayyid Ibrahim, mereka secara eksplisit mengharamkan bagi wanita yang bepergian sendiri. Ini disebabkan karena meraka melihatnya dari sisi hukum (fiqh) yang cenderung pada pemahaman tekstual. Tetapi sebaliknya, kalau kita melihat pada pendapat Qardhawi, maka lafadz "La atau La Yahillu” diatas, bukan

\footnotetext{
${ }^{7}$ Yusuf al-Qaradhawi, Metode Memahami Sunnah dengan Benar, terj. Saefullah Kamalie, Jakarta, Media Dakwah, 1994, hal. 231.
} 
berarti apa-apa. Lafadz itu tidak mempunyai konsekuensi hukum yang serius, karena ia melihat dari sisi budaya, bukan sebaliknya.

Namun demikian, kalau pendapat Qardhawi ini dipahami secara general juga akan menimbulkan masalah. Apakah budaya modern itu sudah mengglobal kesemua daerah, atau bahkan ada daerah-daerah tertentu di muka bumi ini justru keadaanya sangat primitif, tidak jauh berbeda dengan situasi dan kondisi di masa Rasulullah hidup, dalam arti keamanan dan keselamatan belum begitu terjamin.

Menurut hemat penulis, dalam memahami hadits semacam ini sebaiknya dibedakan dulu antara hadits itu memuat aspek hukum dan hadits itu sekedar berupa anjuran moral yang sifatnya longgar. Dalam konteks ini, lebih cocok untuk melihat makna larangan wanita bepergian sendiri itu sebagai suatu anjuran moral, yang sebaiknya dilaksanakan, tetapi tidak menjadi masalah untuk diabaikan mengingat situasi dan kondisi budaya setempat sudah tidak mengharapkan keberadaan hadits tersebut sebagaimana yang dikehendaki Qardhawi. Dengan demikian, melihat larangan dalam hadits itu sebagai anjuran moral merupakan pemahaman kompromis untuk menjembatani kedua pemahaman tekstual dan kontekstual tersebut.

\section{Pemahaman Makna Hadits tentang Dunia sebagai Penjara Orang Mukmin dan Surga Orang Kafir}

\section{Pemahaman Tekstual dan Kontekstual}

Haditst tentang hal ini termuat dalam berbagai kitab hadits, dalam syarh kitab tertentu ada kecenderungan perbedaan pemahaman terutama dari prespektif fiqih dan tasawwuf, yang mana keduanya bisa digolongkan pada upaya memehami makna hadits melalui apa yang tersirat di dalamnya.

Syuhudi Ismail menggolongkan hadits ini dalam betuk tamsil, tetapi tidak menutup kemungkinan dapat memahami juga sebagai bukan bentuk tamsil. Kedua pemahaman ini menurutnya, dapat saling melengkapi. Selanjutnya ia menguraikan bahwa, secara tekstual, hadits tersebut menjelaskan bahwa dunia ini adalah penjara bagi orang yang berima. Karenanya, selama hidup di dunia orang yang beriman harus selalu dalam penderitaan. Kebahagiaan hidup barulah dirasakan oleh orang yang beriman tatkala 
telah berada dalam surga. Sedangkan bagi orang kafir hidup di dunia ini adalah surge, di akhirat mereka berada dalam neraka. ${ }^{8}$

Pemahaman semacam ini akan berdampak negatif yaitu akan mendorong orang islam kepada sikap fatalistik-pesimistik dalam menghadapi hidup di dunia ini. Akibatnya secara kultural umat islam akan terus tertindas dan tertinggal jauh dari budaya orangorang kafir. Menurutnya, pemahaman yang lebih tepat terhadap petunjuk hadits tersebut adalah pemahaman secara kontekstual, yaitu bahwa kata penjara dalam hadits itu memberi petunjuk adanya perintah berupa kewajiban dan anjuran, disamping adanya larangan berupa hukum haram dan hukum makruh. Bagi orang yang beriman, kegiatan hidup di dunia ini tidak bebas tanpa batas. Ibarat penghuni penjara, maka ia dibatasi hidupnya oleh berbagai perintah dan larangan. Sedang bagi orang kafir, dunia adalah surga sebab dalam menempuh hidup ini ia bebas dari perintah dan larangan tersebut. Pemahaman ini paling tidak masih memberi semangat untuk memajukan budaya dengan kendali moral amal dari pada memahaminya secara tekstual yang akan membelenggu daya kreatifitas umat islam itu sendiri.

Pemahaman seperti diatas tidak jauh berbeda dengan apa yang dikemukakan oleh Imam Nawawi bahwa hadits tersebut berarti setiap orang mukmin itu terikat oleh laranganlarangan di dunia yang berkaitan dengan hawa nafsu, sesuatu yang telah diharamkan dan juga hal-hal yang telah dimakruhkan. Dan ia juga dibebani untuk berbuat kebajikan. Apabila meningga ia bebas dari dari ikatan ikatan semacam itu, dan berpindah ke surga yang tidak ada kekurangan dan ikatan-ikatan sebagaimana dunia. Sedang orang kafir selama hidup did dunia bebeas berbuat apa saja bagaikan di surga, tetapi ketika diakhirat nanti mereka diadzab dan berada dalam penderitaan selama-lamanya. ${ }^{9}$

Kedua pemahaman diatas nampak melihat lafadz penjara itu dari sisi fiqih yang berupa aturan aturan, ikatan-ikatan dan larangan-larangan, yang haram dan makruh, dan ini semua mebelenggu orang mukmin selama hidup di dunia.

Namun demikian, makna hadits tersebut akan tampak berbeda ketika di pahami oleh Musthofa Abdul Qadir Atah. Menurutnya, hadits tersebut menunjukkan bahwa orang mukmin itu selalu rindu ingin bertemu dengan Allah. Oleh karenanya kehidupan di dunia ini terasa sempit. Keinginan mereka di dunia hanya satu, menemukan kecintaan

\footnotetext{
${ }^{8}$ M.M Syuhudi Ismail, hadits nabi yang Tekstual dan Kontekstual: Telaah Ma'ani Hadits tentang Ajaran Islam yang Universal, Temporal, dan Lokal, Jakarta, Bulan Bintang, 1994, hal. 17.

${ }^{9}$ Imam Nawawi, Sahih Muslim bi Syarhi al-Imam al-Nawawi, Juz 3, Beirut: Dar al-Fikr, 1983, hal. 93.
} 
dan kedekatan kepada Allah dalam setiap perkara, baik yang pelik maupun yang sederhana. Dengan demikian dunia seolah-olah bagaikan penjara. Orang yang selalu merindukan kepada Allah, tingkah laku dzahirnya tertuju kepada ketaatan kepadanya, sedang batinnya terarah kepada kecintaan kepada Allah. Bagaikan di penjara, mereka ingin cepat- cepat keluar darinya yang terasa sempit, dan menuju kepada tuhannya yang maha luas. ${ }^{10}$

\section{Analisis makna}

Dari kajian makna hadits diatas, pada dasarnya berbagai pendapat yang dikemukakan oleh Syuhudi Islamil, Imam Nawawi, Musthafa Abdul Qadir Atha' bermuara pada dua pemaknaan lafad "sijnun" yang berbeda, yang dikaitkan dengan lafadz "al-dunya" yang pertama memaknai sebagai akumulasi dari aturan, larangan dan ikatan yang selalu menyertai orang mukmin, yang bisa digolongkan pada kacamata fiqih, dan yang kedua memandangnya lebih sebagai suatu kesempitan, karena orang mukmin hanya merindukan Allah, dan ini bisa dimasukkan dalam prespektif sufistik. Sedangkan kata "jannah" di pandang sebagai salah satu bentuk kebebasan berbuat, tanpa aturan dan larangan.

Kalau ditinjau lebih mendalam apa yang telah dikemukakan diatas, terasa ada sesuatu yang kuarang mengena. Makna penjara dalam kaitannya dengan dunia disini lebih di titik beratkan pada suatu tempat dan aturan aturannya, dan fungsinya baik secara hukum, sosial, dan politik. Dan dalam realitas sering kita saksikan penjara sebagai suatu permainan politik dan hukum. Orang yang tidak bersalah justru yang dipenjara karna adanya sintemen politik. Sedang mereka yang bersalah justru malah tertawa, mengejek yang dipenjara. Realitas ini memang aneh, tetapi inilah dunia.

Dari pemahaman makna “jannah” juga masih ada sesuatu yang rancu. Jannah lebih disimbolkan pada kebebasan berbuat yang cenderung berifat negatif. Padahal surga itu tempat orang-orang yang beriman dan bertakwa, sehingga walaupun bebas mereka tidak akan berbuat yang negatif. Dari sini berarti ada makna jannah yang lain yang lebih representatif. Disamping itu, apakah benar bahwa ada orang kafir yang itu benar-benar bebas berbuat sesuka hati di dunia ini, kalau sudah terikat oleh suatu negara, budaya,

\footnotetext{
${ }^{10}$ Musthafa Abdul Qadir, Nawadiru al-Ushul fi Ma'rifati Ahadits al-Rasul li al-Imam al-Turmuzi, Juz 3, beirut: Dar al Kutub al-Ilmiyah, 1993, hal.367-369.
} 
dan hukum setempat yang berlaku, pasti tidak bebas sepenuhnya. Mereka pasti punya aturan dan kita pun punya aturan tersendiri. Jadi yang membedakan bukan pada kebebasannya, tetapi pada perbedaa aturannya.

Menurut hemat penulis, untuk memahami hukum hadits ini dengan baik, dan lebih mencerminkan realitas yang ada, perlu kita tinjau kembali salah satu fungsi Rasul diutus keduniaini sebagaimana yang telah disebutkan terdahulu,yaitu untuk menjelaskan apa yang terkandung dalam al-qur'an. Oleh karena itu, kita perlu merujuk kembali pada teks al-qur'an yang berkaitan dengan dunia.

Kata "dunya" dalam al-qur'an banyak disebutkan diberbagai surat dan ayat. Tetapi dalam permasalahan ini perlu kita lihat Dua ayat yang bersifat umum. Pertama, dijelaskan dalam al-qur'an bahwa:"sesungguhnya kehidupan dunia itu hanyalah suatu permainan dan senda gurau". 11 dan ayat lain disebutkan bahwa: "sesungguhnya kehidupan dunia itu hanyalah berupa kesenangan yang memperdayakan". ${ }^{12}$ Kalau kita merujuk pada teks ini, maka makna penjara dalam hadits itu berarti permainan senda gurau. Memang dalam realitasnya penjara lebih berfungsi sebagai permainan bagi mereka yang berkuasa untuk menjatuhkan rival politiknya, atau untuk mempertahankan status quo. Dan ini suatu saat akan berubah, dan akan memperdayakan mereka sendiri. Dan kalau dikaitkan dengan makna hadits ini lebih bermakna sebagai peringatan bagi oang mukmin agar berhati-hati dalam mengarungi hidup di dunia ini, serta waspada terhadap segala permainan dan tipu daya yang ada, karena dunia ini selalu berubah situasi dan kondisinya dan tidak kekal sebagaimana yang tersimbol dalam kata penjara. Sementara itu, kata "jannah" kalau dirujuk dalam al-qur'an, akan tampak bahwa ia merupakan sesuatau yang menyenangkan, penuh dengan kenikmatan, dan kekal sifatnya. Oleh karenanya, ketika jannah ini di kaitkan dengan orang kafir itu memandang dunia sebagai tempat untuk mencari kesenangan dan kenikmatan yang dipandangnya sebagai sesuatu yang di kenal abadi. Dan mereka juga menganggap tidak ada kehidupan lagi setelah kehidupan di dunia ini. Kehidupan di dunia adalah segala sesuatu yang final.

\section{Reinterpretasi Makna Hadits Pemimpin dari Suku Quraisy}

${ }^{11}$ Q.S. Al-An'am: 32
${ }^{12}$ Q.S. Al-Imran: 185 
Ada beberapa redaksi tentang hadits yang artinya :

"Dalam urusan (beragama, bermasyarakat, dan bernegara) ini, orang quraisy selalu (menjadi pemimpinnya) selama mereka masih ada walaupun tinggal dua orang saja." Redaksi hadits yang lain yang artinya : "Pemimpin itu dari suku quraisy.,"14

\footnotetext{
${ }^{13}$ Shahih Muslim, Juz 3, p. 1452: Shahih al-Bukhari, juz 4, p. 234: Musnad Ahmad, Jilid 2, hal. 29, Lu'lu' wa al-Marjan, hadits No. 1194, hal. 239.

${ }^{14}$ Musnad Ahmad, Juz 3, hal. 129 dan 183.
} 


\section{interpretasi tekstual.}

Ada beberapa ulama yang memahami hadits ini secara tekstual. Misalnnya al-Qurtubi, ia mengatakan bahwa kepala negara disyaratkan harus dari suku quraisy. Sekiranya pada suatu saat orang yang bersuku quraisy tinggal satu saja, maka dialah yang berhak menjadi kepala negara. ${ }^{15}$

Semakna dengan pemahaman diatas adalah apa yang dikemukakan oleh Imam Nawawi. Menurutnya, hadits-hadits ini dan yang seredaksi dengannya adalah bukti nyata bahwa kepemimpinan itu khusus untuk orang Qurais, tidak boleh diambil alih oleh suku lainnya. Pendapat ini selanjutnya dijadikan ijma' dalam memilih pemimpin pada masa sahabat dan juga setelahnya. Mereka yang menyimpang dari aturan ini dicap sebagai ahlu bid'ah. Bahkan persyaratan pemimpin dari suku Quraisy ini sudah menjadi madzhab ulama' secara keseluruhan. Dalam sejarah dapat dilihat bahwa Khalifah Abu Bakar dan Khalifah Umar Bin Khattab melegitimasi hadits ini atas orang-orang Anshar setelah peristiwa meninggalnya Rasulullah, dan tidak seorangpun mengingkarinya. ${ }^{16}$

Kemudian Al-mawardi, dengan mengambil argumentasi historis apa yang telah dilakukan oleh Khalifah Abu Bakar di atas, juga memasukkan syarat keturunan Quraisy ini sebagai salah satu syarat wajib bagi penguasa tertinggi. ${ }^{17}$ Demikian juga halnya dengan Ibnu Hazm, ia menempatkan suku Quraisy sebagai syarat utama bagi kepala negara di samping syarat-syarat lainnya. ${ }^{18}$

Dari berbagai pendapat di atas yang memahami haditst ini mereka itu tergolong dalam ulama ahlu al-sunnah. Tetapi dalam kacamata orang-orang khawarij dan syiah, haditst ini justru di tinggalkan. Orang khawarij tidak mempersoalkan apakah seorang pemimpin itu harus dari suku qurais atau bukan, atau harus dari orang Arab atau bukan yang prinsip baginya seorang pemimpin itu harus mempunyai kemampuan. Sedang bagi golongan syiah yang prinsip adalah mereka yang dari ahlu al-bait.

\section{Interpretasi Kontekstual}

\footnotetext{
${ }^{15}$ Ahmad bin Ali Ibnu Hajar al-Asqalani, Fath al-Bari Syarh Shahih al-Bukhari, juz 13, Beirut, Dar alFikr, t.t. hal.118

${ }^{16}$ Imam Nawawi, Shahih Muslim Bisyarhi al-Imam al-Nawawi, hal.200

${ }_{17}$ Al-Mawardi, al-Ahkam al-Sultaniyah, Beirut Dar al-Fikr, t.t. hal.4-5

18 M. Ysuf Musa, Politik dan Negara dalam Islam, Terj. M. Thalib, Yogyakarta, Pustakan LSI, 1991, hal.60
} 
Orang yang bisa dikatakan pertama kali memahami hadits ini secara kontekstual adalah Ibnu Khaldun, seorang sosiolog muslim yang terkemuka. Dari kacamata sosial inilah ia memahami makna hadits tersebut, yang sekaligus menunjukkan suatu perbedaan interpretasi dan juga suatu upaya untuk pemekaran makna hadits.

Ibnu Khaldun menilai bahwa ketika mengatakan hadits ini Rasulullah menyaksikan adanya rasa 'ashabiyah yang kuat pada diri orang-orang Quraisy yang bisa dijadikan syarat utama untuk menegakkan kekhalifaan. Oleh karena itu, syarat utama bagi kaum muslimin untuk memilih kepala negara harus berasal dari kesetiakawanan yang kuat supaya orang-orang selainnya mau tunduk dan taat, sehingga kesatuan pendapat dan persatuan dapat terpelihara dengan baik. Dengan demikian, syarat keturunan Quraisy tersebut sebenarnya hanya merupakan syarat simbolik saja. ${ }^{19}$

\section{Analisis konteks}

Dari berbagai pemahaman di atas, baik secara tesktual yang cenderung mengikat hadits sedemikian ketat dan kontekstual yang ingin melonggarkan fungsi hadits itu untuk dunia islam yang luas, pada dasarnya ada celah-celah tertentu yang tidak bisa dimengerti dan dipahami dalam perkembangan politik dan model kepemimpinan yang berkembang di berbagai negara dengan jargon demokrasinya.

Memahami hadits tersebut secara tekstual, sebagaimana yang telah dikemukakan oleh para ulama di atas, justru akan mempersulit aplikasi hadits di berbagai negara islam yang berbeda budaya dan suku-sukunya. Untuk konteks Indonesia, misalnya, kalau hadits ini dipahami secara tekstual maka tidak ada artinya sama sekali, justru akan mempertajam disintegrasi.

Di sisi lain, pemahaman kontekstual sebagaimana yang di kemukakan oleh Ibnu Khaldun, juga belum mengena untuk perkembangan politik, atau suksesi kepemimpinan nasional. Jika suku Quraisy dipahami dari sisi 'ashabiyah maka ini akan menimbulkan sentimen sosial.

Pada dasarnya, untuk memperkaya makna dan fungsi hadits ini secara kontekstual harus dicari terlebih dahulu fundamental struktur dari suku Quraisy yang lebih representatif untuk perkembangan perpolitikan nasional maupun internasional dewasa ini. Dalam paradigma politik sekarang tidak dikenal lagi istilah suku sebagai jalurnya, tapi melalui

\footnotetext{
${ }^{19}$ Ibnu Khaldun, al-Muqaddimah, Beirut, Dar al-Fikr, t.t, p. 94
} 
jalur partai dan demokrasi. Oleh karena itu, akan lebih cocok kalau suku Quraisy ini dilihat sebagai partai dan ciri-ciri yang melekat padanya jangan dilihat dari 'ashabiyahnya, tetapi dilihat dari jumlahnya yang mayoritas. ${ }^{20}$ Mempunyai pengaruh yang kuat terhadap masyarakat banyak, berwibawa dan teguh memegang pada nilainilai keagamaan. Ini berarti mereka itu mempunyai kualitas sumber daya manusia yang bagus.

\section{Penutup}

Dari berbagai kajian di atas nampak bahwa pemahaman terhadap teks hadits itu selalu mengalami dinamika, tidak ubahnya dalam paradigma penafsiran al-qur'an. Istilah pemahaman tekstual dan kontekstual yang selama ini didengungkan oleh para cendekiawan muslim kontemporer, merupakan suatu pemetaan saja, bukan suatu model pemecahan atau jalan alternatif yang ideal, dan masalah ini tetap merupakan suatu yang masih problematik, perlu dikaji ulang dan dikembangkan lagi.

Beberapa hadits yang menjadi bahan kajian di atas, paling tidak memberikan gambaran riil, bahwa suatu teks hadits ketika dipahami oleh ulama yang berbeda spesialisasi keilmuannya, atau dilihat dari kacamata yang berbeda, seperti dari sisi fiqih,sufistik, sosial-politik, sosial-budaya, dan lainnya, maka hadits itu akan mekar sesuai dengan tinjauannya di atas. Tawaran-tawaran alternatif yang penulis sajikan dalam kajian di atas, itupun masih bisa dikembangkan dengan pendekatan dan metode yang lain.

Kalau pemahaman suatu teks hadits sebagaimana yang telah diuraikan di atas dikaitkan dengan kerangka pemikiran filosofis yang dapat menopang pemahaman tersebut, yaitu hermeneutikanya Gadamer yang mencoba melihat realitas (termasuk teks) itu keperluan masa depan, J. Habermas yang menggambarkan bahwa pemahaman realitas itu pasti dipengaruhi oleh suatu kepentingan, dan empirismennya David Hume dengan jargonnya being as a peceived being menandaskan bahwa realitas itu ada sebagaimana dipahami subyek. Jika, model pemikiran filosofis yang terakhir itu dijadikan kacamata untuk memahami teks-teks hadits diatas, maka semua pemahaman hadits baik secara tekstual dan kontekstual di atas semua benar, karena makna hadits itu tergantung dari orang yang memahaminya. Pemahaman teks hadits 'pemimpin dari suku Quraisy' yang

\footnotetext{
${ }^{20}$ Abu Zahrah menyebutkan bahwa suku Quraisy itu adalah suku mayoritas dan berpengaruh. Lihat, Inu Zahrah, tarikh al-Mazdahib al-Islamiayh fi al-Siyasah wa al- 'Aqidah, beirut, Dar al-Fikr, t.t p. 71
} 
dikemukakan oleh al-Mawardi misalnya, adalah ideal menurut dirinya, dan pemahaman Ibnu Khaldun ideal menurut dirinya, dan demikian juga pemahaman menurut penulis adalah ideal menurut penulis sendiri. Mana yang paling ideal dari semua ideal di atas. Allahu a 'lamu bi al-shawab 


\section{Daftar Pustaka}

Al-Asqalani, Ahmad bin Ali Ibnu Hajar, Fath al-Bari Syarh Shahih al-Bukhari, juz 13, Beirut, Dar al-Fikr, t.t.

Al-Bukhari, Abu Abdillah Muhammad bin Ismail, Shahih al-Bukhar, Beirut, Dar alFikr.tt.

Al-Mawardi, al-Ahkam al-Sultaniyah, Beirut Dar al-Fikr, t.t.

Al-Naisaburi, Abu al-Husein Muslim bin al-Hajjaj al-Qusyairi., Shahih Muslim, Beirut, Dar al-Fikr.

Al-Qaradhawi, Yusuf, Metode Memahami Sunnah dengan Benar, terj. Saefullah Kamalie, Jakarta, Media Dakwah, 1994.

Al-Zurqani, Muhammad bin Abd al-Baqi bin Yusuf., Syarh al-Zurqani 'ala muwatta' Imam Malik, Juz 4, Beirut: Dar al-Kutub al-Ilmiah, 1990.

Baqi, Muhammad Fuad Abdul. Lu'lu'wa al-marjan fi ma Ittafaqa 'Alaihi al-Syaikhuna, Jilid 2, Beirut, Dar al-Fikr.

Hanbal, Ahmad Bin, Musnad Ahmad, Beirut, Dar al-Fikr.tt.

Ibrahim, Majdi Sayyid., 50 Wasiat Rasulullah Bagi Wanita, Terj. Kathur Suhardi, Jakarta, Pustaka al-Kautsar, 1995.

Ismail, M.M Syuhudi., hadits nabi yang Tekstual dan Kontekstual: Telaah Ma'ani Hadits tentang Ajaran Islam yang Universal, Temporal, dan Lokal, Jakarta, Bulan Bintang, 1994.

Khaldun, Ibnu., al-Muqaddimah, Beirut, Dar al-Fikr, t.t. 
Musa, M. Yusuf,Politik dan Negara dalam Islam, Terj. M. Thalib, Yogyakarta, Pustakan LSI, 1991.

Nawawi, Imam, Shahih Muslim Bisyarhi al-Imam al-Nawawi, Beirut, Dar al-Fikr, t.t.

Nawawi, Imam., Sahih Muslim bi Syarhi al- Imam al-Nawawi, Juz 3, Beirut: Dar alFikr, 1983.

Qadir, Musthafa Abdul, Nawadiru al-Ushul fi Ma'rifati Ahadits al-Rasul li al-Imam alTurmuzi, Juz 3, beirut: Dar al_Kutub al-Ilmiyah, 1993.

Zahrah, Ibnu, Tarikh al-Mazdahib al-Islamiayh fi al-Siyasah wa al-'Aqidah, beirut, Dar al-Fikr, t.t. 